History and Drama 



\section{History and Drama}

The Pan-European Tradition

Edited by Joachim Küpper, Jan Mosch and Elena Penskaya 
This book is published in cooperation with the project DramaNet, funded by the European Research Council

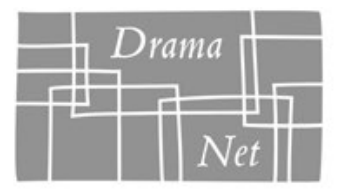

Early Modern European Drama and the Cultural Net

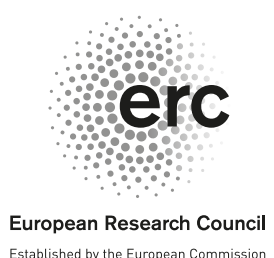

Established by the European Commission

ISBN 978-3-11-060426-9

e-ISBN (PDF) 978-3-11-060427-6

e-ISBN (EPUB) 978-3-11-060436-8

\section{(cc) BY-NC-ND}

This work is licensed under the Creative Commons Attribution-NonCommercial-NoDerivatives 4.0 License. For details go to https://creativecommons.org/licenses/by-nc-nd/4.0/.

\section{Library of Congress Control Number: 2018956629}

\section{Bibliografic information published by the Deutsche Nationalbibliothek}

The Deutsche Nationalbibliothek lists this publication in the Deutschen Nationalbibliografie; detailed bibliografic data are available on the Internet at http://dnb.dnb.de.

(C) 2019 Joachim Küpper, Jan Mosch and Elena Penskaya, published by Walter de Gruyter GmbH, Berlin/Boston

Cover image: photodeedooo/iStock/Thinkstock Typesetting: Integra Software Services Pvt. Ltd.

Printing and binding: CPI books $\mathrm{GmbH}$, Leck

www.degruyter.com 